\title{
Assessment of occupational risk of oil industry workers in extraction of energy resources with regard to fatigue
}

\author{
Polina Shinkevich ${ }^{1}$, Tatiana Kaverzneva ${ }^{*}$, and Natalia Leonova ${ }^{1}$ \\ ${ }^{1}$ Peter the Great St.Petersburg Polytechnic University, 195251 St. Petersburg, Russia
}

\begin{abstract}
Assessment of the occupational risk of oil industry workers is an important aspect of compliance with safety requirements at oil industry enterprises in the extraction of energy resources. Solving the engineering problems facing the extraction of energy resources, including the tasks of assessing occupational risk, it is necessary to take into account as many factors as possible that affect the safe performance of work on the extraction of energy resources. The article deals with the impact of workers' fatigue on their safety, and also a methodology for assessing the occupational risk of oil industry workers taking into account their fatigue is developed.
\end{abstract}

\section{Introduction}

One of the most widespread industries is the oil industry. In many ways, oil resources and their excavation predetermine the development of the country's economy [1-5]. However, despite the importance and prevalence of the oil industry, it still remains one of the most dangerous spheres of activity for both humans and nature [6]. Therefore, industrial injuries at oil industry enterprises, in spite of the general downward trend in industrial injuries in Russia, remain at a high level and represent a serious problem [7, 8].

An essential role in reducing industrial injuries and protecting the health of workers is played by the assessment of occupational risks, which makes it possible to determine the hazards that can pose a threat to the worker's life and health, to evaluate them and take appropriate measures to eliminate these hazards or mitigate the consequences of their implementation [9-11]. When assessing occupational risk, it is very important to take into account as many factors as possible that affect the safe performance of work.

One of the factors that affects the safety of workers, in particular those of the oil industry, is fatigue, which has an adverse effect on a person's performance, reducing his productivity, attentiveness and vigilance. This, in its turn, may lead to the risk of emergencies, the consequences of which at oil industry enterprises have one of the most negative effects on human health [12].

There exist various methods for assessment of occupational risk. However, they do not establish the relationship between fatigue and the level of occupational risk. It can be

* Corresponding author: kaverztt@mail.ru 
assumed that taking into account the change in fatigue of oil industry workers during the work shift will make it possible to more fully assess the level of occupational risk of workers in this field.

In foreign studies, it is noted that there are several objective and subjective methods for assessing fatigue. Objective methods are based on measurements and studies of brain activity, eye movement, cardiovascular reactions [13]. Subjective methods for assessing fatigue are based on questioning of oil industry workers. These methods have their drawbacks, as filling out the questionnaires can take up to 40 minutes [14].

The application of methods for assessing occupational risk makes it possible to take into account a multitude of factors affecting the safety of workers and to prevent accidents, thereby reducing the frequency of injuries at the enterprise.

The purpose of this study was to develop a methodology for assessing the occupational risk of oil industry workers with regard to their fatigue.

\section{Methods and materials}

First of all, the already developed methods for assessing occupational risk that are used in Russia were analyzed. During the analysis it was found out that none of the methods takes into account the change in workers' fatigue during the work shift.

In order to make it possible to take into consideration the degree of fatigue of oil industry workers in the methodology under development, the work [15] was considered.

Further, the factors that affect the level of the worker's occupational risk were analyzed in order to take into account the most significant factors.

By synthesizing the data obtained, a method for assessing the occupational risk of oil industry workers with regard to their fatigue was developed.

Basic terms and definitions: occupational risk assessment, fatigue, oil field, special assessment of working conditions (SAWC).

\section{Results}

For use in the methodology for assessing occupational risk of changes in fatigue during the work shift, the formula (1) [15] was taken:

$$
K_{\text {fat }}=1+0.37 \cdot \mathrm{T} \text {, }
$$

where $\mathrm{T}$ is the time from the beginning of the work shift, expressed in shares.

With the help of this function, the effect of fatigue on the level of occupational risk can be accounted.

When assessing occupational risk, occupational factors, the impact of which can lead to occupational diseases, shall be taken into consideration. Therefore, when developing the methodology, the data obtained during the SAWC were taken into account, since with the help of this measure the following factors are identified and the degree of their impact on the worker is assessed: factors that arise and adversely affect the worker in the course of performance of his professional duties; factors characterizing the severity of the work performed, as well as the tension; availability of means protecting workers and reducing the negative impact of hazardous production factors or harmful production factors on them; factors that depend on the worker's compliance with safety requirements at the hazardous industrial facility.

The assessment of these factors was carried out in points (from 0 to 10), since this method of assessment is simple and clear in the process of implementation. Also, standards were established for each factor. 
The first and second groups of factors were assessed by points depending on the known classes of working conditions: 0 points - optimal (class 1); 1 point - acceptable (class 2); 2-8 points - harmful (class 3); 10 points - hazardous (class 4).

The third group of factors was assessed as follows: 0 points - all necessary PPE, 4-8 points - PPE does not meet the requirements, is defective or inconvenient, 10 points - complete absence of PPE.

For the fourth group of factors, the following distribution was accepted: 0 points - all safety requirements are met, 4-8 points - the requirements for equipment operation are not fully met, 10 points - non-compliance with the established rules, which can lead to harm to the worker's health.

After assigning appropriate points to all factors, the level of occupational risk was calculated (2) taking into account (1):

$$
\mathrm{R}=\left(S_{\max }+\frac{\sum_{\mathrm{i}=1}^{\mathrm{n}} F_{1}+\sum_{\mathrm{j}=1}^{\mathrm{n}} F_{2}+\sum_{\mathrm{a}=1}^{\mathrm{n}} F_{3}+\sum_{\mathrm{b}=1}^{\mathrm{n}} F_{4}}{(\mathrm{i}+\mathrm{j}+\mathrm{a}+\mathrm{b})-1}\right) \cdot K_{f a t}
$$

where $\mathrm{R}$ is the risk level in points,,

$\mathrm{S}_{\max }$ is the maximum score for all four factors,

$\mathrm{F}_{1.2 .3 .4}$ is the point assigned to the first, second, third and fourth factors, respectively,

$\mathrm{K}_{\text {fat }}$ it the fatigue coefficient.

After calculating the level of occupational risk, the resulting value in points is compared with different levels of risk, ranked as follows: 0-1 point - the lowest level of occupational risk; 1.1-2 points - an acceptable level; 2.1-4 points - an average level; 4.1-5.9 points - a high level; 6-10 points - the maximum level.

\section{Discussions and conclusions}

The developed methodology for assessing occupational risk takes into account the factors affecting the worker in the process of work activity, and also allows to take into consideration the influence of the degree of workers' fatigue on the level of occupational risk, which, according to the proposed hypothesis, makes such assessment more complete.

When monitoring the worker's state during the day, the probability that the level of occupational risk will move to the next, higher level decreases significantly.

The advantage of application of this risk assessment methodology is that it can be carried out without any special equipment, which simplifies the risk assessment procedure. The developed methodology can be used at oil industry enterprises. On the basis of this methodology, methods for assessing occupational risk for other industries can be developed.

\section{References}

1. A.P. Solomonov, Orientiry`strategicheskogo razvitiya neftyanogo $i$ neftepererabaty 'vayushhego kompleksa RF (korporativny jo aspekt), Sbornik materialov VI Mezhdunarodnoj nauchno-prakticheskoj konferenczii, 70-78 s6 (2014)

2. T.T. Kaverzneva, O.V. Smirnova, Vliyanie iznosa stroitel nogo oborudovaniya $i$ ruchnogo instrumenta na usloviya truda rabochikh, Bezopasnost' v tekhnosfere, \#3 (42), maj-iyun', S. 14-18 (2013)

3. I. L. Skrypnik, Y. G. Ksenofontov, T. T. Kaverzneva, N. V. Rumyantseva, V. V. Kiss, Assessment of technical level of new, promising models of equipment at the stage of their development in modern engineering practice, Paper presented at the IOP Conference Series: Materials Science and Engineering, , 862(4) doi:10.1088/1757899X/862/4/042031(2020) 
4. T.T. Kaverzneva, E.A. Danilova, Sovershenstvovanie sistemy`okhrany 'truda na ob 'ekte neftegazovoj otrasli, Nedelya nauki SPbPU: materialy` nauchnogo foruma s mezhdunarodny'm uchastiem. Institut voenno-tekhnicheskogo obrazovaniya i bezopasnosti, SPb. : Izd-vo Politekhn. un-ta, 298 s (s 191-193) (2015)

5. T. T. Kaverzneva, N. V. Rumyanczeva, N. A. Leonova, V. I. Salkuczan, I. L. Skripnik, Motivacziya bezopasnogo povedeniya cheloveka, XXI vek: itogi proshlogo i problemy` nastoyashhego plyus, T. 9 №1(49), S 206-212 (2020)

6. V.I. Senina, Oczenka professional `ny 'kh riskov operatorov tovarny 'kh na neftepererabaty vayushhem predpriyatii, Dal'nevostochnaya vesna, 224-226 s (2018)

7. Ezhegodny`e otchety`o deyatel 'nosti Federal `noj sluzhby` po e'kologicheskomu, tekhnologicheskomu i atomnomu nadzoru 2008-2017gg, [E`lektronny j resurs] Rezhim dostupa: http://www.gosnadzor.ru/public/annual_reports/

8. L. Kireeva, T. Kaverzneva, R. Shaydullina, A. Farkhutdinova, Analysis of Tools for Determining Professional Suitability to Perform Hazardous Construction Works. In: Murgul V., Pukhkal V. (eds), International Scientific Conference Energy Management of Municipal Facilities and Sustainable Energy Technologies EMMFT 2019, EMMFT 2019, Advances in Intelligent Systems and Computing, vol 1258. Springer, Cham. (2021)

9. N.V. Chudinin, V.A. Kiryushin, I.S. Rakitina, Oczenka professional nogo riska, kak metod prognozirovaniya sostoyaniya zdorov ya rabotnikov, zanyaty 'kh vo vredny $k h$ usloviyakh truda, Nauka molody`kh - Eruditio Juvenium, № 1, 5-11 s (2013)

10. T. Kaverzneva, D. Tarkhov, A. Uljanov, V. Senchenko, C. Pshenichnaya, I. Alibekova, Criteria for ensuring acoustic safety in the assembly shops of machine-building enterprises, Paper presented at the IOP Conference Series: Materials Science and Engineering, 643(1), doi:10.1088/1757-899X/643/1/012119 (2019)

11. N. Rumyantseva, E. Primak, A. Uljanov, V. Kiss, Assessment of an occupational risk using injury safety indicators, Paper presented at the IOP Conference Series: Materials Science and Engineering, 666(1), doi:10.1088/1757-899X/666/1/012090 (2019)

12. K.S. Romokhov, E’lementy` konczepczii ustojchivogo razvitiya v deyatel ’nosti neftegazovy`kh kompanij, Moskovskij e’konomicheskij zhurnal, № 1, 505 s. (2020)

13. R.K. Mehta, S.C. Peres, P. Kannan, J. Rhee, A.E. Shortz, M. Sam Mannan, Comparison of objective and subjective operator fatigue assessment methods in offshore shiftwork, Journal of Loss Prevention in the Process Industries, 48, pp 376381 (2017)

14. K. McCulloch, T. Kontou, S. Ferguson, Fatigue risk management: A case study.. Society of Petroleum Engineers - SPE/APPEA, Int. Conference on Health, Safety and Environment in Oil and Gas Exploration and Production 2012: Protecting People and the Environment - Evolving Challenges, 3, pp. 2266-2273 (2012)

15. A. V. Korobov, Oczenka professional ’nogo riska rabotnikov TE`K kak odnogo iz osnovny'kh e`lementov sistemy` upravleniya okhranoj truda: dissertacziya ... kandidata tekhnicheskikh nauk: 05.26.01, FGBOU VO «Naczional`ny`j issledovatel`skij universitet «ME`I», 74 s (2018) 